\title{
Study on the Enzymatic Activity of the Soil in Racos Protected Area from Brasov
}

\author{
LILIANA AVASILCAI ${ }^{1}$, GEANINA BIREESCU ${ }^{2}$, MADALINA VIERIU ${ }^{1 *}$, NELA BIBIRE ${ }^{1}$, \\ FLORINA CRIVOI ${ }^{1}$, OANA CIOANCA ${ }^{1 *}$, IONELA-DANIELA MORARIU ${ }^{1}$ \\ ${ }^{1}$ Grigore T. Popa University of Medicine and Pharmacy Iasi, Faculty of Pharmacy, 16 University Str., 700115, Iasi, \\ Romania \\ ${ }^{2}$ Institute of Biological Research Iasi, 47 Lascar Catargi Str., Iasi 700107, Romania
}

\begin{abstract}
Soil enzymes are vital for maintaining soil fertility and health, as they play a crucial role in initiating and maintaining the biogeochemical cycles of the nutrients, in providing fundamental support for fertility for healthy plant growth, and for protecting the environment by degrading pollutant molecules. The aim of the study was the characterization of the soil from the Racos volcano area situated in the southern part of the East Carpathian Mountains, from the point of view of the enzymatic activities of invertase, urease, catalase and dehydrogenase. The values of the index of the total enzymatic activity - TEI, and of the geometric mean of the enzymatic activities - GME, were calculated using the experimental results of the determinations of the enzymatic activity of invertase as $\mu \mathrm{g}$ glucose/g soil/h, of urease as $\mu \mathrm{g} \mathrm{NH}_{4}{ }^{+}-\mathrm{N} / \mathrm{g}$ soil/h, of dehydrogenase as $\mu \mathrm{g}$ triphenylformazan/g soil/h, and of catalase as $\mathrm{mL} 0,02 \mathrm{M} \mathrm{KMnO}_{4}$ solution/g soil/h.
\end{abstract}

Keywords: volcano soil, enzymatic activity, invertase, urease, catalase, dehydrogenase

\section{Introduction}

The natural reserve "Bazaltele de la Racos" was declared a protected area by Government Decree no. 1581 on December 8th, 2005, published in The Official Journal of Romania no. 24 from January 11th, 2006, that established the regime of natural area for new areas. From an administrative point of view, the reservation belongs to the village of Racos in the homonymous commune of Brasov County. It is located on the right bank of the Olt River (Figure 1), where Harghita and Baraolt Mountains meet Perșani Mountains at $480 \mathrm{~m}$ altitude, in the northeastern part of the county $\left(46^{\circ} 01^{\prime} 28^{\prime \prime} \mathrm{N}\right.$ and $\left.25^{\circ} 24^{\prime} 33^{\prime \prime} \mathrm{E}\right)$.

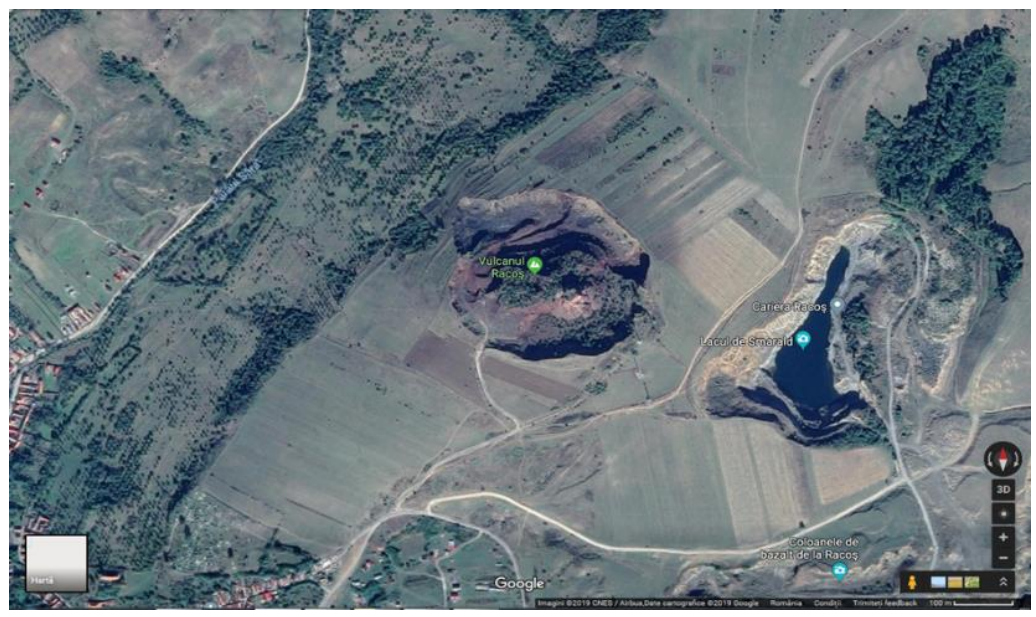

Figure 1. Satellite image of the protected area Racos, Brasov county (source: Google maps)

*email: madalina.vieriu@umfiasi.ro; oana.cioanca@umfiasi.ro 
Racoș area is located in the extreme southern part of the East Carpathian eruptive chain; the Hawaiian-type eruptive activity of the Racoș volcano is considered relatively recent. The basalt volcanites include the territory between Racoșu de Jos, Bogata, Hoghiz, Lupsa and Comana. The position of the basalts in the Racoșu de Jos area shows that the effusive activity occurred at the earliest in the lower Pleistocene, and the volcanic-sedimentary sequence from the basaltic surface consists of sands, gravels, microconglomerates, sandy clays and products of basaltic explosive activity such as scores, lapilli, volcanic bombs, ashes, tuffs [1]. Those characteristics are supported and complemented by recent research that determined the phreatomagmatic structure of the Racos volcano (with southward orientation of the lava), the volume of strombolian cones $\left(1,960,700 \mathrm{~m}^{3}\right)$ and the lava flows $\left(9,957,290 \mathrm{~m}^{3}\right)$, formation that cover a $122,410 \mathrm{~m}^{2}$ area, and 1,016,645 $\mathrm{m}^{2}$, respectively [2].

According to the Romanian System of Soil Taxonomy, the dominant soils in the Perșani Mountains are the acidic brown ones, present especially under the beech forests. There are brown podzolic soils in the north-eastern part, under beech and oak forests, and there are feriiluvial podzolic brown soils under beech forests and under mixed forests of beech and spruce in the central-southern region. Locally, there are also lithosoils and rocks. Rendzines have developed isolated, on limestone, and in the wetlands of meadows there are pseudogleic soils [3].

Soil quality and soil health are two terms commonly used in the literature to describe the functional status of that environmental element. According to the Soil Science Society of America, soil quality is "the ability of a particular soil type to ensure the functioning of natural ecosystems, to support biological productivity, maintain environmental quality, and promote plant and animal health". Soil health is a term used in an ecological sense and it describes the soil as a living and dynamic system whose function is mediated by living organisms and their interactions, but it also underlines that the soil ecosystem needs maintenance and conservation to support the present biodiversity and biological activity [4]. Soil health can be assessed by means of an indicator, called soil health index, which establishes five classes of soils according to the scores assigned to the values of the physical, chemical, biochemical and pollution parameters evaluated: healthy soil, little, medium, strongly and very strongly affected by natural factors and human activity [5].

Microflora is the key factor in mineralizing and transforming soil nutrients through microbial enzymes, which can be secreted extracellular enzymes or endogenous enzymes of the microbial cells. The microbial community itself, at one point, dictates nutrient availability and thus soil health [6]). Extracellular enzymes are secreted into the soil environment, where they decompose or transform the organic and inorganic forms of nutrients to obtain available forms [7]. Those enzymes, generically called soil enzymes, are vital for maintaining soil fertility and health, and for protecting the environment by degrading pollutant molecules [8].

The main plant nutrients that make up the structural and functional molecules of the plant body are $\mathrm{C}, \mathrm{H}, \mathrm{O}, \mathrm{N}, \mathrm{P}$ and $\mathrm{K}$. Secondary nutrients such as $\mathrm{Ca}, \mathrm{Mg}, \mathrm{S}$, and micronutrients such as $\mathrm{B}, \mathrm{Cl}, \mathrm{Cu}, \mathrm{Fe}$, $\mathrm{Mn}, \mathrm{Mo}$ and $\mathrm{Zn}$ are also important for plant growth. Of those, $\mathrm{C}, \mathrm{H}$ and $\mathrm{O}$ are derived from $\mathrm{CO}_{2}$ and $\mathrm{H}_{2} \mathrm{O}$ through photosynthesis, and absorption in soil, respectively. Other nutrients are obtained in mineral form from the soil.

Soil enzymes play a vital role in initiating and maintaining the biogeochemical cycles of those nutrients and provide fundamental support for fertility for healthy plant development [9]. Soil enzymes increase the rate of decomposition of organic residues by facilitating the contact area of the reactants (e.g. substrate and water during hydrolysis) and release nutrients into the sap. The rhizosphere is a unique environment in which microorganisms may selectively develop. Thus, enzymatic activities determine the efficiency of nutrition in soil-plant ecosystems and are more dominant in the rhizosphere compared to soil that mediates mineral biogeochemistry [10]).

Some of the most important enzymes in the soil are those involved in $\mathrm{C}, \mathrm{N}, \mathrm{P}$ and $\mathrm{S}$ cycles. Enzymes involved in the $\mathrm{C}$ cycle (amylase, maltase, cellulase, lignase) cannot directly provide nutrients for plant growth, but are necessary for the proliferation of soil microorganisms that promote plant growth through various mechanisms as they degrade complex organic substances and releases 
simple compounds such as sugars and organic acids. The enzymes of the $\mathrm{N}$ cycle (protease, urease, nitrate reductase, deaminase, amidase), of the $\mathrm{P}$ cycle (phosphomonoesterases, phosphodiesterase, phytase) and of the $\mathrm{S}$ cycle (sulfatase) mineralize inorganic nutrient substances from organic soil, compounds that can be used by both microorganisms and plants. Dehydrogenase is involved in the proton transfer to a number of substrates that accept/donate $\mathrm{H}^{+}$(organic acids, alcohols, $\mathrm{CO}_{2}$, etc.) and represent a general indicator of soil microbial activity [11].

The type of enzymes, their enzymatic activities and their endurance in the soil are influenced by the physical properties of the soil ( $p \mathrm{H}$, texture and structure) because those factors regulate the availability of nutrients for microorganisms, and thus, their activity is reflected in microbial respiration and microflora diversity [9]. Sandy soils are more aerated than clay soils, but the low content in organic substances limits the growth of microorganisms. The microbial population in those soils is characterized by low density and diversity. The production of enzymes by microorganisms in alkaline and saline soils with high $\mathrm{pH}$, or those involved in the use of plant residues and other substrates is much reduced [6]. In the case of degraded soils due to the chemical treatment of the crops, the fertility of the soil and its production potential are much reduced [12]. By adding manure and biofertilizers in soil and through restoration of degraded soil (addition of gypsum in alkaline soils, lime in acidic soils and manure in soils contaminated with heavy metals), soil microbial population increases and thus increasing soil fertility [6].

Plant residues embedded in soil are mineralized by soil biota to produce nutrients needed for plant growth [13]. Soil microorganisms accelerate the rate of decomposition by producing enzymes and they influence the kinetics of plant nutrients in the soil. The rhizosphere roots provide large quantities of organic acids with small molecular weight that act as a carbon source for soil microflora and that have a primary effect on enzyme production, leading to accelerated release of nutrients in the form of inorganic ions [14]. The released inorganic ions act as chelating agents and form a temporary complex with other nutrients as well as enzymes [15]. The complex then decomposes and releases the enzymes and the nutrients in available forms in the rhizosphere. Some soil enzymes degrade toxic compounds into non-toxic compounds or reduce the absorption of toxic metals by plant roots by chelating them into complex combinations [16-18].

Each enzyme is specific to a particular substrate or to a group of similar substrates, which fall within the active reaction site of the enzyme under optimal reaction conditions, forming an enzymesubstrate complex. In the complex, the enzyme catalyzes the reaction and subsequently dissociates, thus becoming free to bind to another substrate molecule and to continue its activity. During the reaction, from the initial complex to the release of the final product, the enzyme undergoes a series of conformational changes compared to the enzymatic form in native state. Enzymes are adsorbed on soil particles and remain active for long periods, because they are protected against environmental factors, for example, protection against photodegradation [4].

The aim of the study was the characterization of the soil from the Racoș volcano area from the point of view of the enzymatic activities of invertase, urease, catalase and dehydrogenase.

\section{Methods and materials}

The soil samples were collected in the first decade of November 2018, from the volcanic crater, but also from the natural pasture on the surface of the crater, from 0-25 cm depth (Figure 2). Two sets of soil samples (corresponding to the volcanic crater and natural pasture) were collected, each set consisting of 10 samples that were used to determine the enzymatic activity of dehydrogenase, catalase, urea and invertase in three repetitions for each enzyme. 


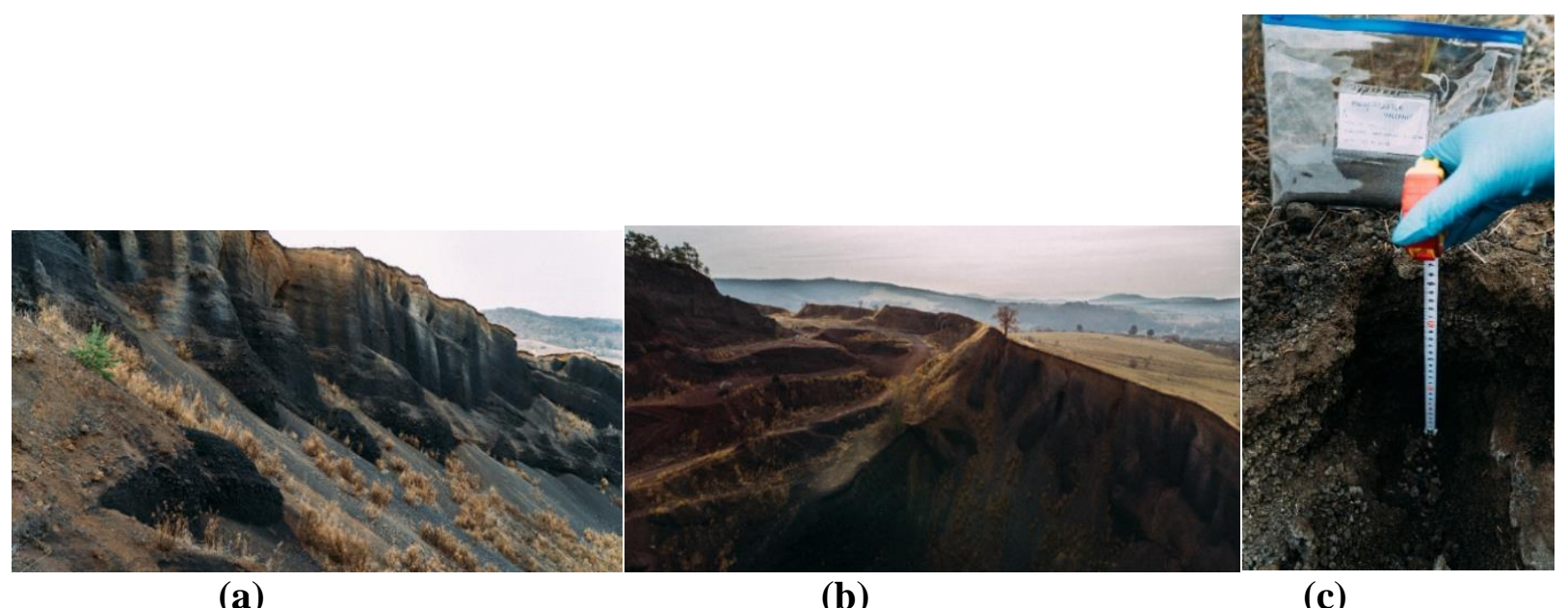

(a)

(b)

(c)

Figure 2. Area for collecting soil samples from crater (a), pasture (b) and depth of harvest (c) - (photo by student Cosmin Bolohan: $3^{\text {rd }}$ November 2018, Racos)

The evaluation methods of the activity of soil enzymes (invertase, urease, dehydrogenase, catalase) were very sensitive and they were adapted to the characteristics of the soil analyzed based on the principles for determining the aforementioned enzymes according to the methods described by Tan et al. 2014 [19-21].

For the determination of the enzymatic activity of invertase, $5 \mathrm{~g}$ of soil previously dried at room temperature, were brought into a conical flask and mixed with $5 \mathrm{~mL}$ distilled water and $15 \mathrm{~mL} 8 \%$ sugar solution. After $24 \mathrm{~h}$ of incubation at $37^{\circ} \mathrm{C}$, it was centrifuged for 5 minutes at $4000 \mathrm{rpm} .1 \mathrm{~mL}$ of supernatant was treated with $3 \mathrm{~mL} \mathrm{3,5-dinitrosalicylic} \mathrm{acid} \mathrm{solution,} \mathrm{and} \mathrm{the} \mathrm{mixture} \mathrm{was} \mathrm{heated} \mathrm{for}$ 5 minutes in a water bath. After cooling to room temperature the glucose content was determined spectrophotometrically at $508 \mathrm{~nm}$. Enzyme activity was expressed as $\mu \mathrm{g}$ glucose $/ \mathrm{g}$ soil/hour.

The method was based on the reduction of 3,5-dinitrosalicylic acid to 3-amino-5-nitro-salicylic acid by the glucose released through the effect of invertase on the carbohydrate substrates present in the soil. The resulting red-brown compound (figure 3) had a maximum absorbance peak at $508 \mathrm{~nm}$.

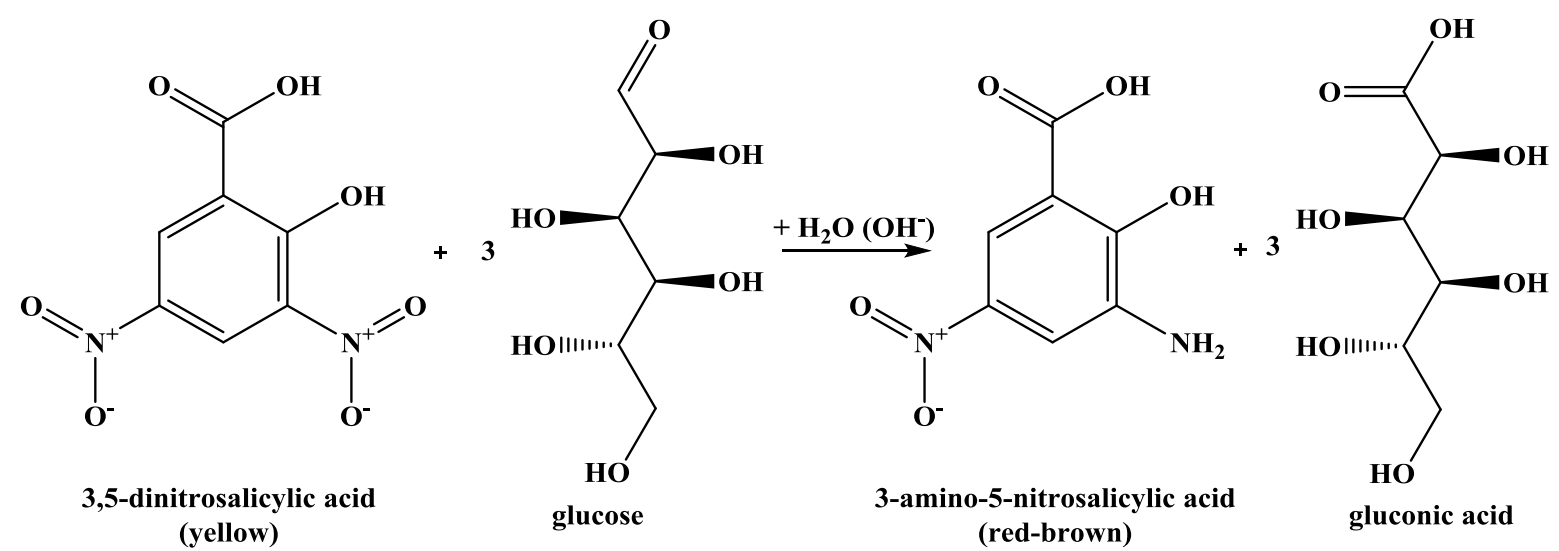

Figure 3. Equation of the oxidation reaction of glucose released by invertase

For the determination of the enzymatic activity of urease, a mixture of $5 \mathrm{~g}$ of soil previously dried at room temperature, $20 \mathrm{~mL}$ distilled water and $10 \mathrm{~mL} 10 \%$ urea solution was incubated for $24 \mathrm{~h}$ at $37^{\circ} \mathrm{C}$. The suspension was then centrifuged at $4000 \mathrm{rpm}$ for $5 \mathrm{~min} .1 \mathrm{~mL}$ of supernatant was treated with $4 \mathrm{~mL}$ of reagent obtained by mixing $100 \mathrm{~mL} 6.6 \mathrm{M}$ phenol solution and $100 \mathrm{~mL} 6.8 \mathrm{M} \mathrm{NaOH}$ solution, and then $3 \mathrm{~mL}$ of $0.9 \%$ sodium hypochlorite solution were added. The ammonia released was quantified calorimetrically at $578 \mathrm{~nm}$. The enzyme activity was expressed as $\mu \mathrm{g} \mathrm{NH}_{4}{ }^{+}-\mathrm{N} / \mathrm{g}$ soil/h. 
For the determination of the enzymatic activity of dehydrogenase, $3 \mathrm{~g}$ of soil previously dried at room temperature was mixed with a solution of triphenyl tetrazolium chloride as substrate. After homogenization, the soil suspension was incubated for $24 \mathrm{~h}$ at $37^{\circ} \mathrm{C}$. The triphenylformazan (TPF) formed was extracted with methanol and measured spectrophotometrically at $485 \mathrm{~nm}$. Dehydrogenase activity was expressed as $\mu \mathrm{g} \mathrm{TPF} / \mathrm{g}$ soil/hour.

For the determination of the enzymatic activity of catalase, $2 \mathrm{~g}$ of soil dried at room temperature was mixed with $40 \mathrm{~mL}$ of distilled water and $5 \mathrm{~mL}$ of $3 \% \mathrm{H}_{2} \mathrm{O}_{2}$ solution. The resulting suspension was stirred for $20 \mathrm{~min}$ at $150 \mathrm{rpm}$. The residual peroxide was stabilized by adding $5 \mathrm{~mL} 1.5 \mathrm{M} \mathrm{H}_{2} \mathrm{SO}_{4}$ solution and then it was immediately centrifuged at $4000 \mathrm{rpm}$ for $5 \mathrm{~min}$. The peroxide from the supernatant was titrated with $0.02 \mathrm{M} \mathrm{KMnO}_{4}$ solution. Catalase activity was expressed as $\mathrm{mL} 0.02 \mathrm{M}$ $\mathrm{KMnO}_{4} / \mathrm{g}$ soil/hour.

The obtained results were statistically evaluated in terms of arithmetic mean, minimum value, maximum value, and standard deviation. Subsequently, the recorded values were used to calculate two indexes of soil enzymatic activity: total enzyme activity index - TEI and geometric mean of enzymatic activities - GME. Those two indexes are dimensionless parameters that may be used to assess soil quality [19]. The TEI and GME were calculated using the following formulas:

$$
\mathrm{TEI}=\sum_{n=1}^{i} \frac{x_{i}}{\overline{x_{i}}}(\mathrm{n}=1,2,3,4)
$$

$\mathrm{GME}=\sqrt[4]{\text { invertase } \times \text { urease } \times \text { catalase } \times \text { dehydrogenase }}$

\section{Results and discussions}

Due to the increased sensitivity to external interferences, the enzymatic activity of the soil can be considered as an indicator of soil quality. Thus, invertase is partially responsible for the breakdown of plants in soil because sucrose, one of the soluble carbohydrates of plants, is the substrate of action of the enzyme. Urease decomposes urea into ammonia and carbon dioxide, with consequences on soil $\mathrm{pH}$ values. The activity of dehydrogenase is frequently used as an indicator of soil biological activity, while catalase is considered an indicator of the activity of aerobic microorganisms in correlation with both their number and soil fertility [19].

The results obtained when establishing the calibration curves for the determination of the enzymatic activities of invertase, urease and dehydrogenase are shown in table 1.

With regard to the ranges of the enzyme activities of invertase, urease and catalase, minimum, maximum, average and their standard errors are summarized in table 2.

Table 1. Calibration curves equations for the determination of the enzymatic activities

\begin{tabular}{|c|c|c|c|}
\hline No & Enzyme & Equation of calibration curve & $\mathbf{R}^{\mathbf{2}}$ \\
\hline $\mathbf{1}$ & Invertase & $\mathrm{A}=0.019 \mathrm{C}-0.021$ & 0.9974 \\
\hline $\mathbf{2}$ & Urease & $\mathrm{A}=0.0006 \mathrm{C}+0,0029$ & 0.9981 \\
\hline $\mathbf{3}$ & Dehydrogenase & $\mathrm{A}=0.0019 \mathrm{C}-0.001$ & 0.9999 \\
\hline
\end{tabular}

Table 2. Range of variation of enzymatic activity in soil samples

\begin{tabular}{|c|c|c|c|c|c|c|c|c|}
\hline \multirow{2}{*}{$\begin{array}{c}\text { Enzyme } \\
\text { Soil sample }\end{array}$} & \multicolumn{2}{|c|}{$\begin{array}{c}\text { Invertase } \\
\mu \mathrm{g} \text { glucose } / \mathrm{g} \text { soil } / \mathrm{h}\end{array}$} & \multicolumn{2}{|c|}{$\begin{array}{c}\text { Urease } \\
\mu \mathrm{g} \mathrm{NH} 4^{+}-\mathrm{N} / \mathrm{g} \text { soil/h }\end{array}$} & \multicolumn{2}{|c|}{$\begin{array}{l}\text { Dehydrogenase } \\
\mu \mathrm{g} \text { TPF } / \mathrm{g} \text { soil/h }\end{array}$} & \multicolumn{2}{|c|}{$\begin{array}{c}\text { Catalase } \\
\mathrm{mL} \mathrm{0,02M} \mathrm{KMnO}_{4} / \mathrm{g} \mathrm{soil} / \mathrm{h}\end{array}$} \\
\hline & Pasture & Crater & Pasture & Crater & Pasture & Crater & Pasture & Crater \\
\hline $\begin{array}{c}\text { Minimum enzyme } \\
\text { activity }\end{array}$ & 0.0371 & 0.0031 & 0.1105 & 0.0105 & 0.7653 & 0.0254 & 0.6633 & 3.5204 \\
\hline \begin{tabular}{|c|}
$\begin{array}{c}\text { Maximum enzyme } \\
\text { activity }\end{array}$ \\
\end{tabular} & 0.1188 & 0.0191 & 1.1455 & 0.0355 & 4.6748 & 0.7398 & 1.8877 & 6.4115 \\
\hline \begin{tabular}{|c|}
$\begin{array}{c}\text { Average enzyme } \\
\text { activity }\end{array}$ \\
\end{tabular} & 0.0869 & 0.0059 & 0.5884 & 0.0261 & 2.0081 & 0.2576 & 1.0731 & 5.1001 \\
\hline Standard error & 0.0025 & 0.0002 & 0.0315 & 0.0025 & 0.1230 & 0.0270 & 0.1393 & 0.1009 \\
\hline
\end{tabular}


The enzymatic activity of the invertase is presented in Figure 4, comparatively in the soil samples from the natural pasture versus the volcanic crater. The decrease of the enzymatic activity in the volcanic crater by an order of magnitude was noticed when compared to the enzymatic activity of the invertase in the natural pasture soil.

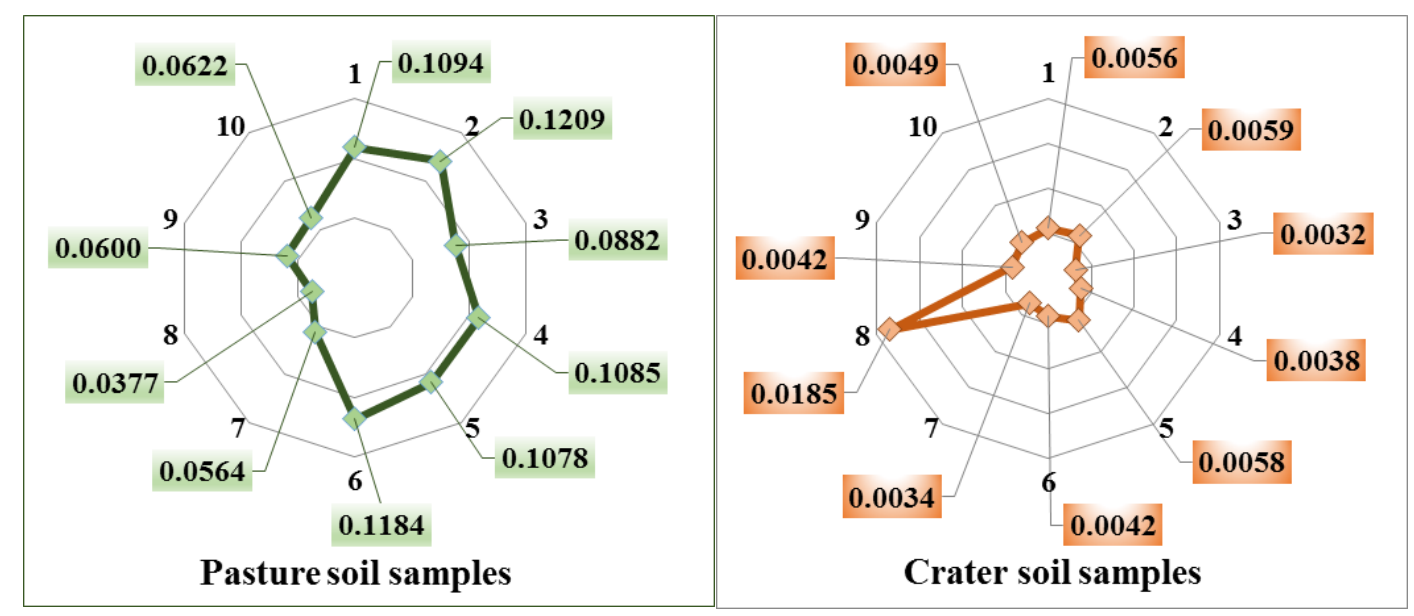

Figure 4. The activity of invertase ( $\mu$ g glucose/g soil/h)

Urease is an enzyme that catalyzes the hydrolysis of urea into carbon dioxide and ammonia through a reaction mechanism based on the formation of carbamate as intermediary. Although it is widespread intra- and extracellularly, urease is rapidly degraded in the soil by proteolytic enzymes [21].

It has been shown that the activity of urease depends on the microbial population, the physical and chemical properties of the soil [22]. Its stability is influenced by organo-mineral complexes and humic substances that increase its resistance to denaturing agents, such as heat and proteolytic attack [23]. In general, urea activity increases with increasing temperature and organic fertilization and decreases with soil tillage [21].

Figure 5 shows a more intense urea activity in the natural pasture soil compared to the enzyme activity in the volcanic crater soil.
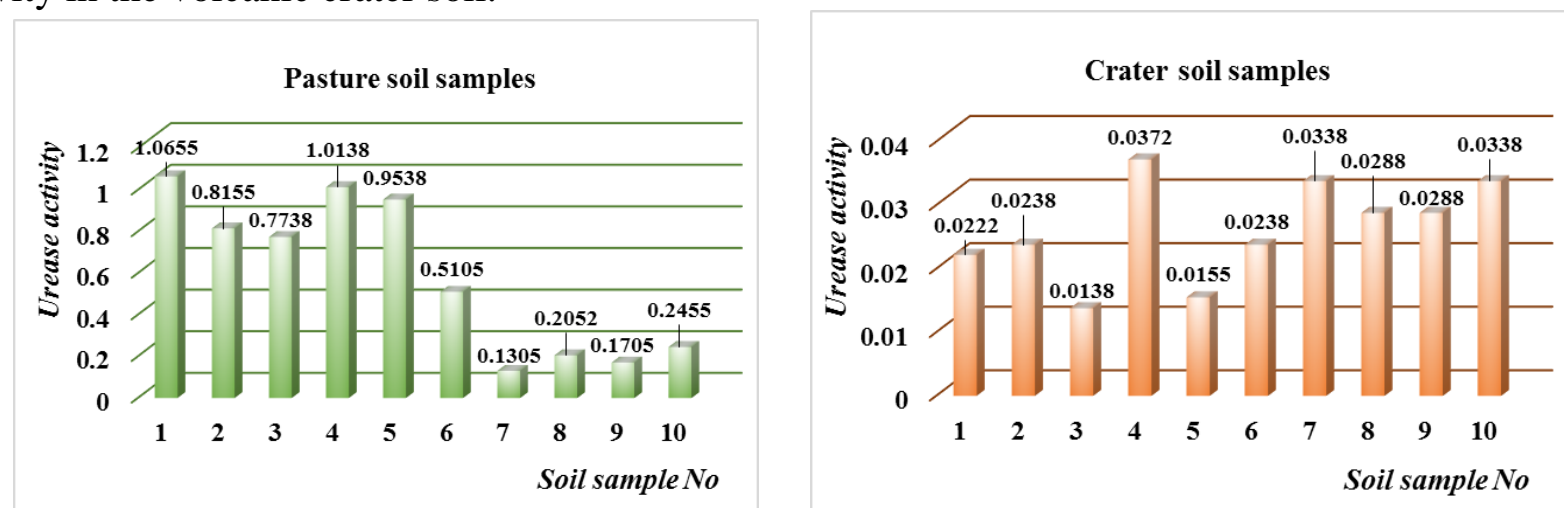

Figure 5. The activity of urease $\left(\mu \mathrm{g} \mathrm{NH}_{4}{ }^{+}-\mathrm{N} / \mathrm{g}\right.$ soil/h)

Dehydrogenase is an enzyme that appears only in soil bacteria of the genus Pseudomonas that oxidizes organic matter by transferring protons and electrons from substrates to acceptors. The enzyme exists as an integral part of intact cells and does not accumulate extra-cellularly in soil. Measurement of dehydrogenase activity is useful for both direct assessment of soil microbial activity and for detecting its type of pollution (e.g. enzyme activity is inversely proportional to pesticide treatments) [21].

The evaluation of dehydrogenase activity in soil bacteria was based on their ability to convert triphenyltetrazolium chloride to triphenylformazan. Higher levels of formazan indicated that bacteria 
were present and healthy, contributing to improved soil fertility. In that respect, Figure 6 revealed that, in the pasture soil, the enzyme had a more intense activity compared to its activity in the crater soil.

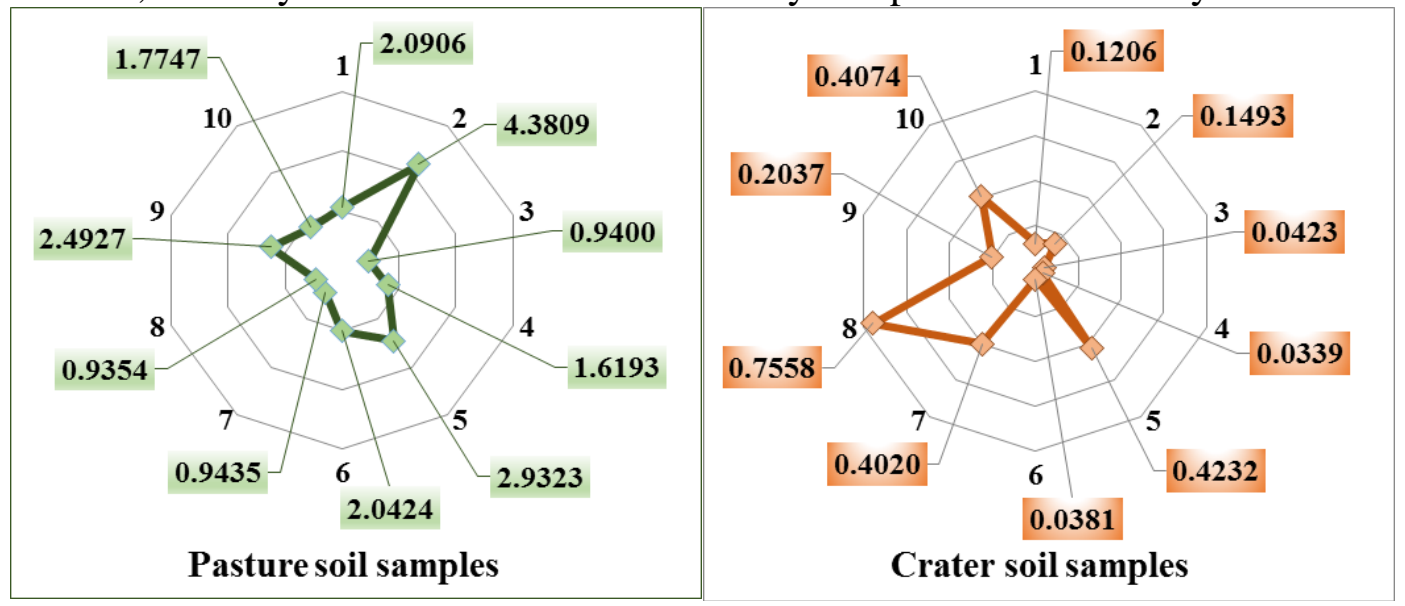

Figure 6. The activity of dehydrogenase ( $\mu \mathrm{g}$ TPF/g soil/h)

Similar to dehydrogenase, catalase is an intracellular enzyme, present in anaerobic and aerobic microorganisms. In general, enzymatic activities of dehydrogenase and catalase can be used to characterize the abundance and metabolic activity of soil bacteria, while their kinetic parameters are used to describe the catalytic activity, origin and affinity of the enzyme substrate [24].

The activity of catalase in soil samples collected from the volcanic crater is shown in Figure 7, compared to the enzyme activity determined in soil samples collected from pasture. It was noticed that the enzyme activity in the volcanic crater was more intense. That fact could be the consequence of plant growth in the volcanic crater because the extraction activities of the volcanic slag had been ceased.
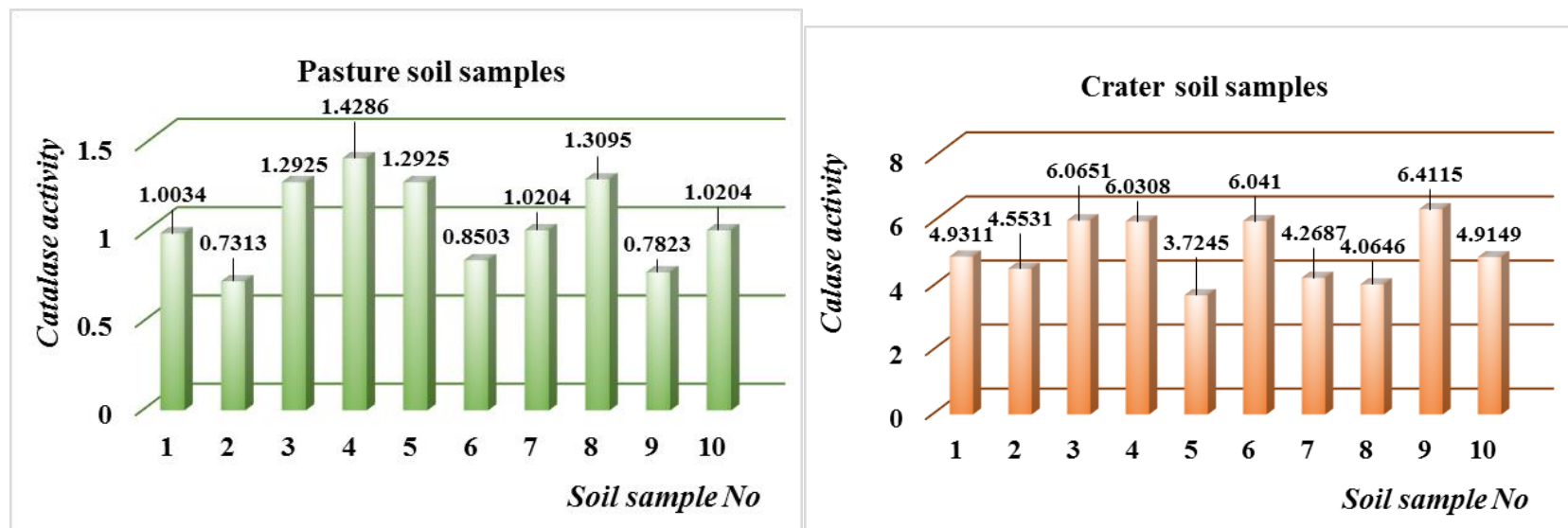

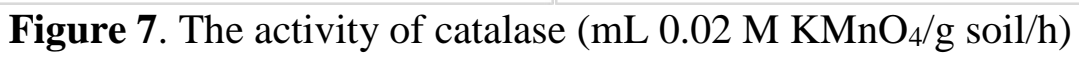

Data from the scientific literature demonstrate the strong relationship between enzyme activity and the quantity and quality of organic matter in soil. High enzymatic activity in the grassland soils is due to the effects of spontaneous vegetation and lack of agricultural work. Our results support the above assertion by values of invertase, urease and dehydrogenase activities greater than 14.72, 22.54, respectively 7.79 times in the pasture soil compared to the activities of the same enzymes determined in the volcanic crater soil [25-29].

The values of the index of the total enzymatic activity - TEI and of the geometric mean of the enzymatic activities - GME, were calculated using the experimental results of 30 determinations and they are presented in Table 3 . 
Table 3.Total characterization

of enzymatic activity in soil

\begin{tabular}{|c|c|c|c|}
\hline \multirow{2}{*}{\multicolumn{2}{|c|}{ Index }} & \multicolumn{2}{|c|}{ Soil sample } \\
\hline & & Pasture & Crater \\
\hline \multirow{2}{*}{ TEI } & Minimum & 1.6138 & 1.7164 \\
\hline & Maximum & 7.4008 & 8.7262 \\
\hline \multirow{2}{*}{ GME } & Minimum & 0.2135 & 0.0412 \\
\hline & Maximum & 1.0468 & 0.2381 \\
\hline
\end{tabular}

Research in the field has shown that TEI and GME are significantly influenced by the soil organic matter content, but also by $p \mathrm{H}$. In general, the content of organic matter positively affects the activity of extracellular enzymes in the soil by protecting the enzymes against soil $p \mathrm{H}$ changes, caused by the adsorption of enzyme molecules on soil particles and/or organic matter. In such cases, the organic $\mathrm{C}$ content and the activity of the enzymes would be linked by means of microbial biomass [19].

From the point of view of $p \mathrm{H}$, it can be stated that the analyzed soil, whether harvested from the crater $(p \mathrm{H}=6.02)$ or from the pasture $(p \mathrm{H}=5.87)$, fell in the category of fertile soils, for which values ranged between 5 and $7 p \mathrm{H}$ units.

\section{Conclusions}

Soil enzymes can be considered as bioindicators of soil quality because they carry the biological imprint of previous soil management in correlation with the structure and the work performed on it. They also reflect the biological balance, fertility, quality and changes in the biological state of the soil due to pollution or human activity.

A more comprehensive and accurate biological indicator than TEI for changes in soil quality can be obtained by including several enzymes as indicators of key soil biological processes. Those indicators could help to make decisions to manage the activities carried out on the ground at local and regional level.

No improvement, landscaping, fertilization or agricultural works have been performed to the pasture situated in the immediate vicinity of the Racoș volcano, and the slag has been exploited up to 30 years ago. Closing the slag quarry and acquiring the protected nature reserve area status in 2005 had beneficial consequences for soil health and tourism activity in the area.

The diversity of grassland vegetation contributed to the growth of microorganisms activity in the soil and the enzymatic activity in the soil of the volcanic crater could be a consequence of plant growth even though it was less developed compared to the pasture.

Acknowledgments: The authors give thanks to students Ștefana Ciobănică and Cosmin Bolohan for their involvement in the soil sampling activity.

\section{References}

1.MIHAILA, N., KREUZER, H., Revista Terra, 4, 1981, p. 37.

2.SEGHEDI, I., POPA, R.G., PANAIOTU, C.G., SZKAS, A., PECSKAY, Z., Bull. Volcanol., 78, no. 10, 2016, p. 69.

3.FLOREA, N., MUNTEANU, I., Sistemul Român de Taxonomie a Solurilor (STRS). Editura Sitech, Craiova, 2012, p. 47.

4.DOTANIYA, M.L., APARNA, K., DOTANIYA, C.K., SINGH, M., REGAR, K.L., Role of soil enzymes in sustainable crop production In: Enzymes in food biotechnology, Academic Press, Cambridge, Massachusetts, 2019.

5.BIREESCU, G., MUNTEANU, N., STOLERU, V., AVASILCĂI, L., BIREESCU, L., EQA, 14, 2014 , p. 1.

6.GIANFREDA, L., RAO, M.A., Enzymes in Agricultural Sciences. OMICS Group eBooks, Heathrow, 2014. 
7.DOTANIYA, M.L., RAJENDIRAN, S., MEENA, V.D., SAHA, J.K., COUMAR, M.V., KUNDU, S., PATRA, A.K., Agric. Res., 6, no. 1, 2017, p. 91.

8.STIRLING, G., HAYDEN, H., PATTISON, T., STIRLING, M., Aust. Plant Pathol., 46, no. 4, 2017, p. 387.

9.FANG, S., LIU, J., LIU, D., XIE, B., Soil Sci. Plant Nutr., 56, no. 3, 2010, p. 483.

10.DOTANIYA, M.L., MEENA, V.D., Proc. Natl. Acad. Sci. India Sec. B: Biol. Sci., 85, no. 1, 2013, p. 1.

11.DAS, S.K., VERMA, A., Role of soil enzymes in maintaining soil health. In: Shukla, G., Verma, A. (Eds.), Soil Enzymology. vol. 1. Springer International, New York, 2011.

12.DOTANIYA, M.L., DATTA, S.C., BISWAS, D.R., DOTANIYA, C.K., MEENA, B.L., RAJENDIRAN, S., REGAR, K.L., LATA, M., Intl. J. Recycl. Org. Waste Agric., 5, 2016, p. 185.

13.BISHT, J.K., MEENA, V.S., MISHRA, P.K., PATTANAYAK, A., Conservation agricultureconservation agriculture-an approach to combat climate change in Indian Himalaya. vol. 1. Springer International, New York, 2016, p. 39.

14.MEENA, V.S., MEENA, S.K., VERMA, J.P., KUMRAR, A., AERON, A., MISHRA, P.K., BISHT, J.K., PATTANAYAKA, A., NAVEED, M., DOTANIYA, M.L., Ecol. Eng., 107, 2017, p. 8.

15.DOTANIYA, M.L., MEENA, V.D., Proc. Natl. Acad. Sci. India Sec. B: Biol. Sci., 85, no. 1, 2013, p. 1.

16.CRIVOI, F., BOGHIU, A.M., PASCU, M.C., VASILE, C., Cell. Chem. Techn., 42, no. 4-6, 2008, p. 179.

17.BURUIANA, T., MELINTE, V., POPA, I.D., BURUIANA, E.C., J. Mater. Sci. Mater. Med., 25, no. 4 , p. 83.

18.BUTNARU, E., AGOROAEI, L., MIRCEA, C., CRIVOI, F., CHINAN, V., TANASE, C., Sgem 8th Int. Sci. Conf. -Conf. Proc., II, 2008, p. 91.

19.TAN, X., XIE, B., WANG, J., HE, W., WANG, X., WEI, G., Sci. World J., 6, 2014, p. 535768.

20.UTOBO, E.B., TEWARI, L., Appl. Ecol. Env. Res., 13, no. 1, 2015, p. 147.

21.CORSTANJE, R., SCHULIN, R., LARK, R., Eur. J. Soil Sci., 58, no. 5, 2007, p. 1087.

22.MAKOI, J., NDAKIDEMI, P., Afr. J. Biotechnol., 7, 2008, p. 181.

23.SHANG, Z.C., ZHANG, L.L., WU, Z.J., GONG, P., LI, D.P., ZHU, P., GAO, H.J., J. Soil Sci. Plant Nut., 12, no. 3, 2012, p. 605.

24.AVELLANEDA-TORRES, L.M., NARVAREZ-CUENCA, C.E., SANCHEZ, J., J. Soil Sci. Plant Nut., 13, no. 2, 2013, p. 301.

25.BLONSKA, E., LASOTA, J., ZWYDAK, M., Forest research papers, 78, no. 1, 2017, p. 39.

26.VUZA, A., ODOCHIAN, L., DUMITRAS, M., NEMTOI, G., CRAUS, M.L., CRIVOI, F., MANEA, F., Rev. Chim., 55, (10), 2004, 808.

27.MORARIU, I.D., AVASILCAI, L., VIERIU, M., PANAINTE, A.D., BIBIRE, N., Rev. Chim., 68 , (2), $2017,304$.

28.VUZA, A., CRAUS, M.L., ODOCHIAN, L., DUMITRAS, M., CRIVOI, F., Rev. Chim., 55, (5), 204, 313.

29.POPA, I.D., SCHIRIAC, E.C., UNGUREANU, D., CUCIUREANU, R., Rev. Rom. Med. Lab., 20, no. 1, 2012, p. 63.

Manuscript received: 31.12.2019 